Article

\title{
Hierarchical Ni-Al hydrotalcite supported Pt catalyst for efficient catalytic oxidation of formaldehyde at room temperature
}

\author{
Zhaoxiong Yan a, Zhihua Xu a,*, Lin Yue a, Ling Shi a, Linyong Huang b,\# \\ a Key Laboratory of Optoelectronic Chemical Materials and Devices of Ministry of Education, Hubei Key Laboratory of Industrial Fume and Dust Pollution \\ Control, Jianghan University, Wuhan 430056, Hubei, China \\ ${ }^{\mathrm{b}}$ Key Laboratory for Processing and Application of Catalytic Materials, Huanggang Normal University, Huanggang 438000, Hubei, China
}

\section{A R T I C L E I N F}

\section{Article history:}

Received 25 May 2018

Accepted 20 July 2018

Published 5 December 2018

\section{Keywords:}

Hydrotalcite

NiAl-layered double hydroxides

Hierarchical structure

Catalytic oxidation

Formaldehyde removal

\begin{abstract}
A B S T R A C T
Catalytic oxidation at room temperature is recognized as the most promising method for formaldehyde (HCHO) removal. Pt-based catalysts are the optimal catalyst for HCHO decomposition at room temperature. Herein, flower-like hierarchical Pt/NiAl-LDHs catalysts with different $\left[\mathrm{Ni}^{2+}\right] /\left[\mathrm{Al}^{3+}\right]$ molar ratios were synthesized via hydrothermal method followed by $\mathrm{NaBH}_{4}$ reduction of Pt precursor at room temperature. The flower-like hierarchical Pt/NiAl-LDHs were composed of interlaced nanoplates and metallic Pt nanoparticles (NPs) approximately 3-4 nm in diameter were loaded on the surface of the Pt/NiAl-LDHs with high dispersion. The as-prepared Pt/NiAl21 nanocomposite was highly efficient in catalyzing oxidation of $\mathrm{HCHO}$ into $\mathrm{CO}_{2}$ at room temperature. The high activity of the hierarchical $\mathrm{Pt} / \mathrm{NiAl} 21$ nanocomposite was maintained after seven recycle tests, suggesting the high stability of the catalyst. Based on in situ diffuse reflectance infrared Fourier transform spectroscopy (DRIFTS) studies, a reaction mechanism was put forward about HCHO decomposition at room temperature. This work provides new insights into designing and fabricating high-performance catalysts for efficient indoor air purification.
\end{abstract}

(C) 2018, Dalian Institute of Chemical Physics, Chinese Academy of Sciences. Published by Elsevier B.V. All rights reserved.

\section{Introduction}

Formaldehyde (HCHO) is widely used in particle board, door panels and coatings for building, furnishing and interior decoration materials. Gaseous HCHO emitted from these industrial products leads to an inevitable air pollutant in indoor environment. HCHO can pose a terrible threat to human health including eyes and nose irritation, headache and respiratory diseases, and even cancer etc. [1-5].

Various methods including physical adsorption [6], chemical oxidation [7,8], photocatalytic degradation [9] and catalytic oxidation [10-13] have been studied to remove gaseous HCHO from indoor air. Among these methods, room-temperature catalytic oxidation of $\mathrm{HCHO}$ into $\mathrm{CO}_{2}$ and water is appealing because of the avoidance of secondary pollution and no need for additional energy input (for heating or light illumination). Supported noble metals are the most effective catalysts for HCHO decomposition at room temperature. It is generally believed that the performances of the catalysts usually rely on the architectures, composition and surface property of the supports, which in turn would affect the particle size, dispersion and stability of the supported noble metal nanoparticles. Most

\footnotetext{
* Corresponding author. Tel: +86-13409925284; Fax: +86-27-84225198; E-mail: xuzhihua78@sina.com

\# Corresponding author. Tel: +86-18871361314; Fax: +86-27-84225198; E-mail: Ly_huang2003@163.com

This work was supported by the National Natural Science Foundation of China $(21577046,21307038)$, Wuhan Morning Light Plan of Youth Science and Technology (2017050304010327) and the Opening Project of Key Laboratory of Optoelectronic Chemical Materials and Devices, Ministry of Education, Jianghan University (JDGD-201813).

DOI: 10.1016/S1872-2067(18)63143-2 | http://www.sciencedirect.com/science/journal/18722067 | Chin. J. Catal., Vol. 39, No. 12, December 2018
} 
of the reducible oxides such as $\mathrm{TiO}_{2}$ [14-16], $\mathrm{MnO}_{2}[17,18]$, $\mathrm{CeO}_{2}[19,20], \mathrm{Fe}_{x} \mathrm{O}_{y}[21-23]$ and $\mathrm{Co}_{3} \mathrm{O}_{4}[24,25]$, are investigated as the support of the noble metals. It is considered that the redox property of the supports favors the formation of a strong interaction between the support and the metal induced by their close contact in nanoscale. This surface interaction resulted from the charge transfer between the noble metal and the support facilitates the generation of active oxygen species, which play an important role in the catalytic oxidation of $\mathrm{HCHO}$ at room temperature. Moreover, non-reducible metal oxides like $\mathrm{SiO}_{2}, \mathrm{Al}_{2} \mathrm{O}_{3}$ [26] and $\mathrm{AlOOH}$ [27] were also found as wonderful supports of noble metal for HCHO decomposition into $\mathrm{CO}_{2}$ and $\mathrm{H}_{2} \mathrm{O}$ at room (or ambient) temperature. The abundance of active surface hydroxyls is responsible for the superior activity. In our previous investigation, ferrihydrite exhibited an excellent activity towards $\mathrm{HCHO}$ oxidation at room temperature, combining a reducible property and plenty of surface hydroxyls [23]. More recently, we reported that $\mathrm{CeO}_{2}$ nanoparticles can enhance formaldehyde oxidation on AlOOH-supported Pt catalyst at room temperature [28], which could be attributed to the combination of the advantages of $\mathrm{AlOOH}$ nanoflakes and reducible ceria. However, the fabrication of efficient nanomaterials with the advantages of reducible supports and abundance of surface hydroxyls for gaseous $\mathrm{HCHO}$ removal at room temperature is still interesting and desirable.

By virtue of the versatility in morphology, composition and architecture [29], layered double hydroxides (LDHs) have been widely used as adsorbents, catalysts, electrochemical materials and catalyst promoters. As a typical two-dimensional brucite $\mathrm{Mg}(\mathrm{OH})_{2}$-like layered inorganic materials, NiAl-LDHs consist of mixed nickel and aluminum hydroxide layers with charge-balancing anions located in the interlayer space. Due to the relatively high redox activity of $\mathrm{Ni}$ and the confinement effect of the hierarchical pores, hierarchical NiAl-LDHs based composites have received much attention in many fields including electrode material [30] and heterogeneous catalysts [31]. For example, Du et al. [31] found that flower-like NiAl-LDHs supported Au catalyst showed an excellent catalytic activity toward alcohol oxidation due to the cooperation of $\mathrm{Ni}$ and $\mathrm{Au}$, and the confinement effect of the hierarchical pores. Taking consideration of the characteristics of the aforementioned supports for room-temperature oxidation of $\mathrm{HCHO}$, hierarchical NiAl-LDHs is expected to be a perfect alternative to support noble metal because it simultaneously possesses the merits of reducible metal species (Ni), abundance of hydroxyls resulted from the hydroxide, and hierarchical nanostructure. The hierarchical pore structure not only favors high dispersion of accessible noble metal nanoparticles, but also promotes diffusion and transport of reactants and products, which are thought as important factors in HCHO catalytic oxidation. To the best of our knowledge, hierarchical NiAl-LDHs nanoflowers as supports of Pt catalysts have not yet been reported for HCHO decomposition at room temperature. Herein, NiAl-LDHs with hierarchical pore structure supported Pt was prepared and investigated for room-temperature catalytic oxidation of HCHO. The composition influence of the flower-like catalysts on the catalytic performance was studied. In addition, the synergistic effects between Ni, Pt and surface hydroxyls were also clarified by identifying the oxidation states and the redox process. Based on the catalyst characterization and DRIFTS analysis, the catalytic reaction mechanism of HCHO over NiAl-LDHs was proposed.

\section{Experimental}

\subsection{Sample synthesis}

Synthesis of support. The hierarchical NIAl-LDHs with different $\left[\mathrm{Ni}^{2+}\right] /\left[\mathrm{Al}^{3+}\right]$ molar ratios were synthesized by a urea decomposition method with the assistance of $\mathrm{NH}_{4} \mathrm{~F}$ as a morphology control agent [31]. In brief, $\mathrm{Ni}\left(\mathrm{NO}_{3}\right)_{2} \cdot 6 \mathrm{H}_{2} \mathrm{O}(0.001 \mathrm{~mol})$ or $(0.002 \mathrm{~mol})$ or $(0.003 \mathrm{~mol}), \mathrm{Al}\left(\mathrm{NO}_{3}\right)_{3} \cdot 9 \mathrm{H}_{2} \mathrm{O}(0.001 \mathrm{~mol})$, urea $(0.02 \mathrm{~mol})$ and $\mathrm{NH}_{4} \mathrm{~F}(0.008 \mathrm{~mol})$ were dissolved in deionized water $(50 \mathrm{~mL})$ with vigorous stirring to give a transparent solution. The resulting solution was aged in a $100-\mathrm{mL}$ sealed Teflon-lined with autoclave at $110{ }^{\circ} \mathrm{C}$ for $36 \mathrm{~h}$. The precipitate was collected by centrifugation, washed with deionized water and ethanol three times and dried in an oven at ca. $80{ }^{\circ} \mathrm{C}$ overnight. The as-synthesized NiAl-LDHs prepared from $0.001,0.002$ or $0.003 \mathrm{~mol}$ of $\mathrm{Ni}\left(\mathrm{NO}_{3}\right)_{2} \cdot 6 \mathrm{H}_{2} \mathrm{O}$ was denoted as $\mathrm{NiAl} 11, \mathrm{NiAl} 21$ and NiAl31, respectively. For the purpose of comparison, the preparation of sole $\mathrm{Ni}$ or Al-containing support was performed similarly, but only $\mathrm{Ni}\left(\mathrm{NO}_{3}\right)_{2} \cdot 6 \mathrm{H}_{2} \mathrm{O}(0.004 \mathrm{~mol})$ or $\mathrm{Al}\left(\mathrm{NO}_{3}\right)_{3} \cdot 9 \mathrm{H}_{2} \mathrm{O}$ $(0.004 \mathrm{~mol})$ was used instead of both of $\mathrm{Ni}\left(\mathrm{NO}_{3}\right)_{2} \cdot 6 \mathrm{H}_{2} \mathrm{O}$ and $\mathrm{Al}\left(\mathrm{NO}_{3}\right)_{3} \cdot 9 \mathrm{H}_{2} \mathrm{O}$, and the obtained samples were abbreviated as $\mathrm{Ni}$ and $\mathrm{Al}$, respectively.

Synthesis of Pt catalyst. $0.4 \mathrm{~g}$ of the as-prepared sample (NiAl11, NiAl21, NiAl31, Ni or Al) was dispersed into $30 \mathrm{~mL}$ of deionized water. Then a certain amount of an aqueous solution of $\mathrm{H}_{2} \mathrm{PtCl}_{6} \cdot 6 \mathrm{H}_{2} \mathrm{O}$ was added into the above suspension under magnetic stirring (with a nominal Pt loading of $0.8 \mathrm{wt} \%$ ). After impregnation for $20 \mathrm{~min}, 5 \mathrm{~mL}$ of a mixed solution of $\mathrm{NaBH}_{4}$ $(0.1 \mathrm{~mol} / \mathrm{L})$ and $\mathrm{NaOH}(0.1 \mathrm{~mol} / \mathrm{L})$ was rapidly added to the suspension under vigorous stirring for $30 \mathrm{~min}$. Finally, the suspension was collected by centrifugation, washed with deionized water and ethanol two times, and dried an oven at ca. $80{ }^{\circ} \mathrm{C}$. The resulting samples were designated as Pt/NiAl11, $\mathrm{Pt} / \mathrm{NiAl} 21, \mathrm{Pt} / \mathrm{NiAl} 31, \mathrm{Pt} / \mathrm{Ni}$ and $\mathrm{Pt} / \mathrm{Al}$, respectively. In addition, the Pt/NiAl21 treated at $150{ }^{\circ} \mathrm{C}$ for $4 \mathrm{~h}$ was denoted as Pt/NiAl21-c.

\subsection{Characterization of the catalyst}

The X-ray diffraction (XRD) patterns of the as-prepared catalysts were obtained by a Philips X'Pert powder X-ray diffractometer (Rigaku, Japan) using $\mathrm{Cu} K_{\alpha}$ radiation $(\lambda=0.15419 \mathrm{~nm})$ at a scan rate of $0.05^{\circ} \mathrm{s}^{-1}$. The morphology and microstructure of the samples were observed on a JEOL JSM-7500 Field emission scanning electron microscopy (FESEM) with a $15 \mathrm{kV}$ accelerating voltage and a JEOL JEM-2100F transmission electron microscope (TEM) with a $200 \mathrm{kV}$ accelerating voltage. Energy-dispersive X-ray spectroscopy (EDS) and elemental mapping analysis of the Pt/NiAl21 sample was carried out on EDS in- 
struments (X-MAXn Oxford, UK). Specific surface area was determined by the multipoint Brunauer-Emmett-Teller (BET) method by nitrogen $\left(\mathrm{N}_{2}\right)$ adsorption data recorded on a Micromeritics ASAP 2020 nitrogen adsorption apparatus (USA), and the pore size distributions (PSD) were determined by assuming the cylindrical pore model using the Barrett-Joyner-Halenda (BJH) method. All samples were degassed at $110{ }^{\circ} \mathrm{C}$ prior to adsorption measurements. Chemical analyses were determined by inductively coupled plasma emission spectroscopy (ICP-AES, Shimadzu ICPS-75000). The X-ray photoelectron spectroscopy (XPS) measurements were performed on an ESCALAB 250xi spectrometer (Thermon Scientific). The binding energy was referenced to the $\mathrm{C} 1 \mathrm{~s}$ peak at $284.8 \mathrm{eV}$ of the surface adventitious carbon. The Fourier transform infrared (FTIR) spectra were collected using a Shimadzu IRAffinity-1 FTIR spectrometer within the wavenumber range of 4000-400 $\mathrm{cm}^{-1}$. Thermogravimetric (TG) analysis was performed on a DTG-60H analyzer (Shimadzu, Tokyo, Japan) in $\mathrm{N}_{2}$ flow $\left(35 \mathrm{~mL} \mathrm{~min}^{-1}\right.$ ) using a heating rate of $10^{\circ} \mathrm{C} \mathrm{min}-1$. Hydrogen temperature-programmed reduction $\left(\mathrm{H}_{2}\right.$-TPR) was carried out on the BELCAT-B (Japan) instrument. The samples were pretreated in $\mathrm{He}(50 \mathrm{~mL} \mathrm{~min}-1)$ at $150{ }^{\circ} \mathrm{C}$ for $1 \mathrm{~h}$ and then the temperature was ramped from room temperature to $600{ }^{\circ} \mathrm{C}$ at $10{ }^{\circ} \mathrm{C} \mathrm{min}-1$ with the introduction of the reducing gas $(10 \%$ $\mathrm{H}_{2} / \mathrm{Ar}$ ) at a flow rate of $30 \mathrm{~mL} \mathrm{~min}^{-1}$. In situ Diffuse Reflectance Infrared Fourier Transform Spectroscopy (DRIFTS) was performed in Thermo Fisher Nicolet 6700 FTIR spectrometer. The catalysts were pretreated in a dried nitrogen flow at room temperature for $1 \mathrm{~h}$ in an in situ cell reactor, and then, the reactant gas mixture $\left(78 \mathrm{ppm} \mathrm{HCHO}+\mathrm{O}_{2}\right)$ was introduced into the DRIFTS cell at room temperature via separate mass flow meters at a flow rate of $30 \mathrm{~mL} \mathrm{~min}^{-1}$. All spectra were recorded with a resolution of $4 \mathrm{~cm}^{-1}$, and the background spectrum was subtracted from each spectrum.

\subsection{HCHO removal test}

The HCHO removal tests were carried out at room temperature in an organic glass box, which was covered with a layer of aluminum foil on its inner wall [32]. The catalyst $(0.1 \mathrm{~g})$ was dispersed on the bottom of a glass petri dish with a diameter of $65 \mathrm{~mm}$. After placing the sample-containing petri dish on the bottom of reactor and covering it with a glass slide, a certain amount of condensed HCHO solution (38\%) was injected into the reactor. Prior to the experiments, HCHO was allowed to volatilize with the assistance of a 5-W fan on the bottom of the reactor, and then the HCHO solution was completely volatilized and reached adsorption-desorption equilibrium within the reactor. The initial concentration of HCHO was controlled at about 223 ppm until the glass slide cover on the petri dish was removed to start the HCHO removal test. The concentrations of gaseous $\mathrm{HCHO}$ and $\mathrm{CO}_{2}$ were on-line monitored by a Photoacoustic Field Gas Monitor (INNOVA Air-Tech Instruments, Model 1412) equipped with TCD detector. During the catalytic oxidation reaction, $\mathrm{HCHO}$ concentration decreased and $\mathrm{CO}_{2}$ concentration increased steadily with time. The $\mathrm{CO}_{2}$ concentration increase (ppm, $\Delta \mathrm{CO}_{2}$ ) is the difference between $\mathrm{CO}_{2}$ con- centration at reaction time $t$ and initial time. The HCHO removal efficiency $(\eta)$ was used to evaluate the performance of the samples, and was calculated according to the following equation:

$$
\eta=\frac{[\mathrm{HCHO}]_{\mathrm{i}}-[\mathrm{HCHO}]_{\mathrm{f}}}{[\mathrm{HCHO}]_{\mathrm{i}}} \times 100 \%
$$

where $[\mathrm{HCHO}]_{\mathrm{i}}(\mathrm{ppm})$ is the initial equilibrium concentration of $\mathrm{HCHO}$ before the test started, and $[\mathrm{HCHO}]_{\mathrm{f}}(\mathrm{ppm})$ is the final concentration of $\mathrm{HCHO}$ at the end of the test.

\section{Results and discussion}

\subsection{Physicochemical properties of the catalyst}

Fig. 1 shows the XRD patterns of the as-prepared samples. For all samples, distinctive XRD peaks can be indexed as the (003), (006), (012), (015), (018), (110), and (113) reflections of a NiAl-LDHs phase [30,33]. Besides the phase of NiAl-LDHs, a diffraction peak at $\mathrm{ca} .18 .5^{\circ}$ related to $\mathrm{Al}(\mathrm{OH})_{3}$ is observed for NiAl11 and Pt/NiAl11 [31]. This indicates the presence of mixing phases in NiAl11 and Pt/NiAl11 samples. Moreover, NiAl11 and Pt/NiAl11 showed weak diffraction peaks of NiAl-LDHs, which is probably due to small crystallite size and weak crystallization of the formed $\mathrm{Al}(\mathrm{OH})_{3}$. Closer observation is seen that the intensities of the diffraction peaks of Pt/NiAl11 and Pt/NiAl21 decreased slightly compared with those of the corresponding NiAl-LDHs, which presumably resulted from the dissolution of aluminum compound after the addition of $\mathrm{NaBH}_{4}$ and $\mathrm{NaOH}$ solution in the process of Pt deposition. Additionally, elemental analysis by ICP-AES reveals that the actual ratio of $\mathrm{Ni} / \mathrm{Al}$ in Pt-containing samples are higher than the corresponding NiAl-LDHs (Table 1), confirming the dissolution of aluminum compound in the preparation process of the supported Pt catalysts [32].

The FTIR spectra of NiAl11, NiAl21, NiAl31, Pt/NiAl11, $\mathrm{Pt} / \mathrm{NiAl} 21$ and Pt/NiAl31 are shown in Fig. 2. For all samples, the bands at $3403-3448$ and $1640 \mathrm{~cm}^{-1}$ are due to the vibration of the hydroxyl groups in the metal hydroxide layer and the water molecules intercalated into the interlayers. The band

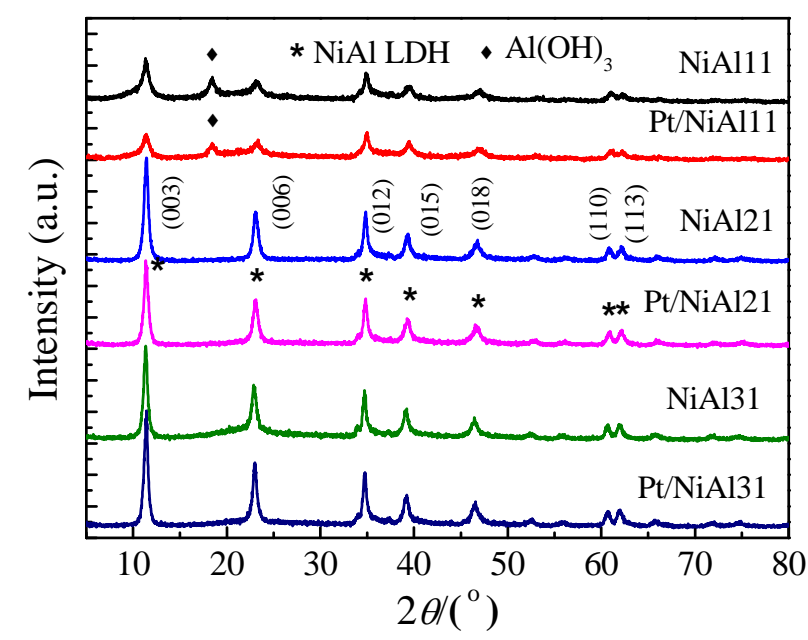

Fig. 1. XRD patterns of NiAl11, Pt/NiAl11, NiAl21, Pt/NiAl21, NiAl31 and Pt/NiAl31. 
Table 1

Results of ICP-AES and XPS analysis of the as-synthesized catalysts.

\begin{tabular}{lccc}
\hline Sample & $\mathrm{Pt}^{\mathrm{a}}(\mathrm{wt} \%)$ & $\mathrm{Ni} / \mathrm{Al}^{\mathrm{a}}(\mathrm{at})$ & $\left(\mathrm{O}_{\mathrm{ads}}+\mathrm{OH}\right) / \mathrm{O}_{\mathrm{L}}$ \\
\hline NiAl21 & 0.00 & $2: 1$ & 0.899 \\
$\mathrm{Pt} / \mathrm{NiAl} 11$ & 0.73 & $1.9: 1$ & 0.418 \\
$\mathrm{Pt} / \mathrm{NiA21}$ & 0.74 & $2.6: 1$ & 1.259 \\
Pt/NiAl31 & 0.74 & $3.3: 1$ & 0.732
\end{tabular}

a Determined by ICP-AES.

at $1358 \mathrm{~cm}^{-1}$ is assigned to the vibrations of interlayer carbonate aions $\left[\mathrm{v}_{3}\left(\mathrm{CO}_{3}\right)\right][30]$, and the bands at $500-800 \mathrm{~cm}^{-1}$ are related to $\mathrm{M}-\mathrm{O}, \mathrm{O}-\mathrm{M}-\mathrm{O}$ and $\mathrm{M}-\mathrm{O}-\mathrm{M}$ lattice vibrations $(\mathrm{M}=\mathrm{Ni}$ and $\mathrm{Al}$ ) $[34,35]$. Closer observation is found that a new peak appear at $1558 \mathrm{~cm}^{-1}$ on the spectra of the supported Pt samples, which can be attributed to the adsorption carbonate anions [36]. The appearance of new peak with carbonate anions indicates that Pt loading altered the surface property of the supports.

As shown in Fig. 3, the three samples exhibited flower-like morphology with hierarchical structure, which were self-assembled by interlaced nanoplates. The morphologies of the supported Pt are similar to those of the unsupported Pt samples (not shown here). The TEM images further confirmed
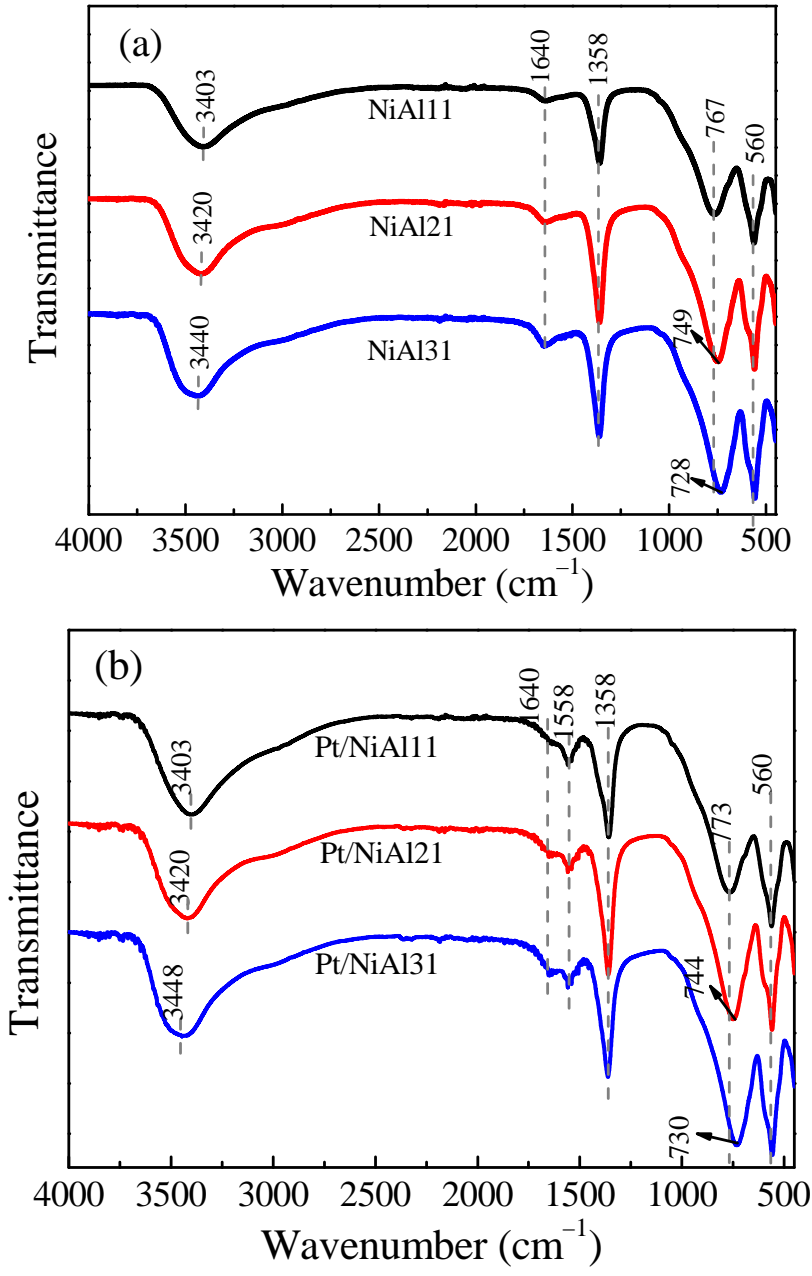

Fig. 2. FTIR spectra of NiAl11, NiAl21 and NiAl31 (a), and Pt/NiAl11, $\mathrm{Pt} / \mathrm{NiAl} 21$ and Pt/NiAl31 (b)

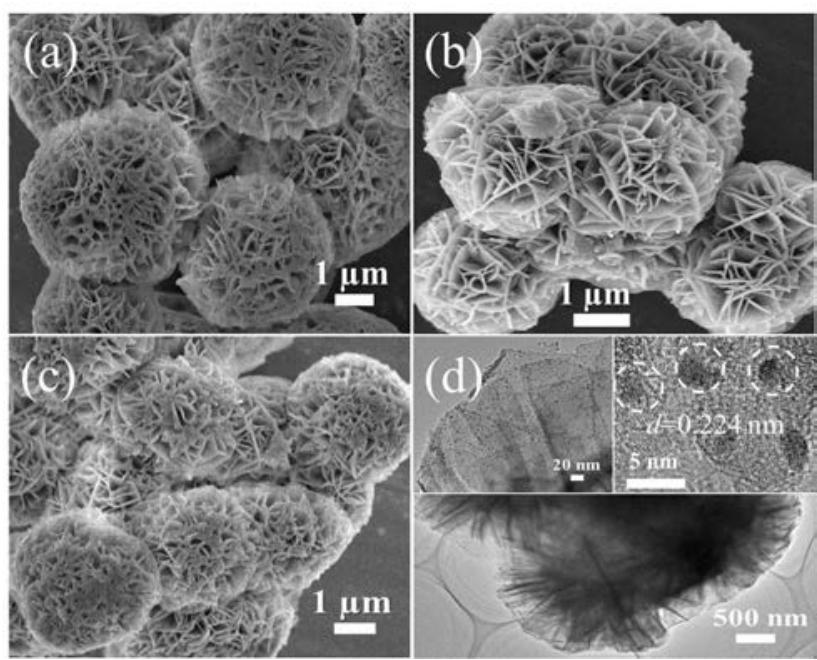

Fig. 3. SEM images of Pt/NiAl11 (a), Pt/NiAl21 (b) and Pt/NiAl31 (c); (d) TEM image of Pt/NiAl21. Insets of Fig. 3(d) are the magnified image of the edge (left) and HRTEM image of Pt nanoparticles (right) of Pt/NiAl21, respectively.

the flower morphology of Pt/NiAl21 consisted of nanoflakes. Image magnification in the left panel (insets of Fig. 3(d)) presented that Pt nanoparticles with size ca. 3-4 nm dispersed evenly on the edge of the flowers. The HRTEM image in the right panel (insets of Fig. 3(d)) showed that the interplanar spacing is ca. $0.224 \mathrm{~nm}$ corresponding to the (111) set of plane for metallic $\mathrm{Pt}$ [23]. This result illustrates that $\mathrm{Pt}^{0}$ is obtained for the catalyst.

Fig. 4 shows the EDS spectrum and element mapping images of Pt/NiAl21. The EDS spectrum indicates that the Pt/NiAl21
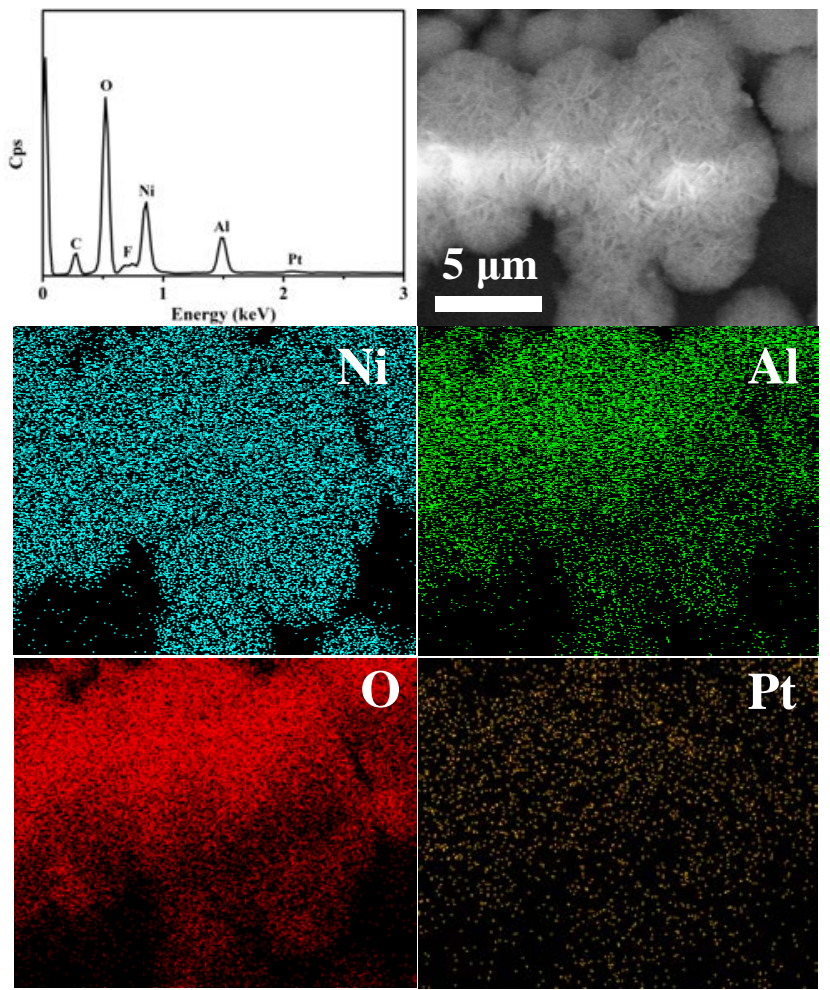

Fig. 4. EDS spectrum and element mapping images of Pt/NiAl21. 
sample is mainly composed of $\mathrm{Ni}, \mathrm{Al}, \mathrm{O}$ and Pt. From the element mapping images, it can be seen that the $\mathrm{Ni}, \mathrm{Al}, \mathrm{O}$ and $\mathrm{Pt}$ elements have homogenous distributions in the microspheres. This observation also provides solid evidence that Pt was successfully deposited on NiAl21.

Fig. 5 shows the nitrogen sorption isotherms and the corresponding pore-size distribution curves of Pt/NiAl11, Pt/NiAl21 and Pt/NiAl31 catalysts. All samples showed type IV isotherms according to Brunauer-Deming-Deming-Teller classification with type $\mathrm{H} 3$ hysteresis loops for Pt/NiAl21 and Pt/NiAl31, and $\mathrm{H} 2$ hysteresis loop in the range of $0.45-0.8\left(P / P_{0}\right)$ and $\mathrm{H} 3$ hysteresis loop in the range of $0.8-1.0\left(P / P_{0}\right)$ for Pt/NiAl11 [37]. The shape of $\mathrm{H} 3$ hysteresis loop is related to the slit-like pores resulted from aggregation of plate-like particles, agreement with the SEM result. H2 hysteresis loop for Pt/NiAl11 indicates an interconnected pore network, which presumably relates to $\mathrm{Al}(\mathrm{OH})_{3}$ aggregated with NiAl-LDHs. All samples presented a quite broad pore-size distribution (Inset in Fig. 5), and contained a small amount of mesopores (peak pore at ca. 2.4-3.0 $\mathrm{nm}$ ), a large number of large mesopores (peak pore at ca. $43-49 \mathrm{~nm}$ ) and macropores. The pore size width ( $\left.d_{\text {pore}}\right)$ at the maximum of the pore size distribution, BET surface areas $\left(A_{\mathrm{BET}}\right)$ and pore volume ( $\left.V_{\text {pore }}\right)$ derived from the isotherms are listed in Table 2. It can be seen that with increasing the molar ratio of Ni/Al, the $A_{B E T}$ of the NiAl-LDHs and their corresponding supported Pt samples increased and then decreased. When the ratio of $\mathrm{Ni} / \mathrm{Al}$ is equal to 2, the resulting samples showed the largest specific surface areas. In addition, the loading of $\mathrm{Pt}$ nanoparticles seemed to have little influence on the pore volume and BET surface areas of the samples, suggesting the bulk supports remained almost intact after a small amount of Pt loading.

The analysis of TG curve for NiAl21, Pt/NiAl11, Pt/NiAl21 and Pt/NiAl31 was shown in Fig. 6. All samples showed two weight losses. The first weight loss below $215{ }^{\circ} \mathrm{C}$ was corresponds to the removal of physicsorbed water on the external surface of the crystallites as well as water interlayer galleries [29,38]; and it was $11.8 \%, 8.6 \%, 11.6 \%$ and $11.6 \%$ for NiAl21, Pt/NiAl11, Pt/NiAl21 and Pt/NiAl31, respectively. The second weight loss at ca $215-600{ }^{\circ} \mathrm{C}$ involves dihydroxylation of the

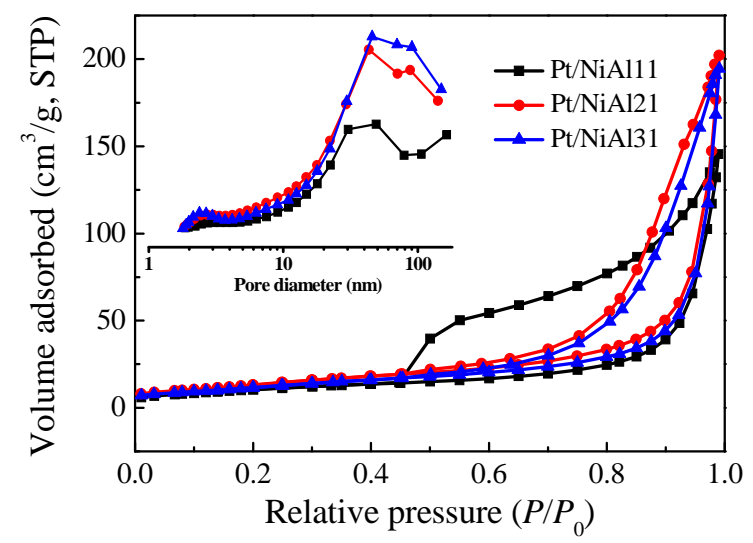

Fig. 5. Nitrogen adsorption-desorption isotherms and the corresponding pore-size distribution curves (inset) of Pt/NiAl11, Pt/NiAl21 and $\mathrm{Pt} / \mathrm{NiAl31.}$
Table 2

Physical properties of the as-synthesized samples.

\begin{tabular}{lcccr}
\hline Sample & $A_{\text {BET }}\left(\mathrm{m}^{2} / \mathrm{g}\right)$ & $d_{\text {pore }}(\mathrm{nm})$ & $V_{\text {pore }}\left(\mathrm{cm}^{3} / \mathrm{g}\right)$ & $\eta(\%)$ \\
\hline NiAl11 & 32 & $2.1,30.3$ & 0.14 & 0.0 \\
Pt/NiAl11 & 39 & $3.0,48.9$ & 0.16 & 69.1 \\
NiAl21 & 50 & $2.4,29.2$ & 0.20 & 0.0 \\
Pt/NiAl21 & 49 & $2.7,43.2$ & 0.20 & 92.4 \\
NiAl31 & 46 & $2.4,29.6$ & 0.20 & 0.0 \\
Pt/NiAl31 & 43 & $2.4,45.7$ & 0.18 & 85.6 \\
\hline
\end{tabular}

layers as well as removal of volatile species $\left(\mathrm{CO}_{2}\right)$ arising from the interlayer carbonate anions [35,39]; and it was $19.7 \%$, 21.6\%, 22\% and 20.7\% for NiAl21, Pt/NiAl11, Pt/NiAl21 and $\mathrm{Pt} / \mathrm{NiAl31}$, respectively. Compared to NiAl21, Pt/NiAl21 showed a larger weight loss in the second regions, indicating it contained more amount of carbonate anions. The result is in agreement with that measured by infrared spectroscopy, further indicative of the alteration of the surface property of support after Pt deposition.

As shown in Fig. 7(a), the samples show two evident peaks at 68.2-68.5 and 74.2-74.4 eV, which are assigned to Ni 3p [40] and $\mathrm{Al} 2 p$ [28], respectively. A new small peak at ca. $70.9 \mathrm{eV}$ appeared on the supported Pt catalysts, which is characteristic of metal Pt. This phenomenon implies that Pt NPs were successfully deposited on the supports.

The Ni $2 p$ XPS of all samples (Fig. 7(b)) split to Ni $2 p_{3 / 2}$ (857.6-858.1 eV) and Ni 2p $p_{1 / 2}(875.5-875.8 \mathrm{eV})$ peaks, which can be assigned to the $\mathrm{Ni}^{2+}$ ion of $\mathrm{Ni}(\mathrm{OH})_{2}$. The appearance of two satellite bands (labeled "Sat.") implies the presence of a high-spin $\mathrm{Ni}^{2+}$ in NiAl-LDHs [41,42]. A positive shift for $\mathrm{Ni} 2 p_{3 / 2}$ is seen as compared to the reported binding energy (BE) value for $\mathrm{Ni} 2 p_{3 / 2}$ in $\mathrm{Ni}(\mathrm{OH})_{2}(855.6-856.6 \mathrm{eV})[3,42]$, suggesting the electron-deficiency in $\mathrm{Ni}(\mathrm{II})$ atoms in the as-prepared samples. The supported Pt catalysts prepared from different molar ratio of $\mathrm{Ni} / \mathrm{Al}$ showed similar $\mathrm{BE}$ values of $\mathrm{Ni} 2 p_{3 / 2}$ and $\mathrm{Ni} 2 p_{1 / 2}$, which are in the range of experimental errors. However, compared to that of Ni $2 p_{3 / 2}$ for NiAl21 $(857.6 \mathrm{eV})$, the BE value of Ni $2 p_{3 / 2}$ for the supported Pt samples (Pt/NiAl21) shifted to $858.1 \mathrm{eV}$. The positive shift of the BE value indicates the surface electron perturbation in $\mathrm{Ni}$ atoms caused by the Pt loading and the electron transfer from Ni to Pt. This also suggests a strong interaction between Pt nanoparticles and $\mathrm{Ni}$ atoms.

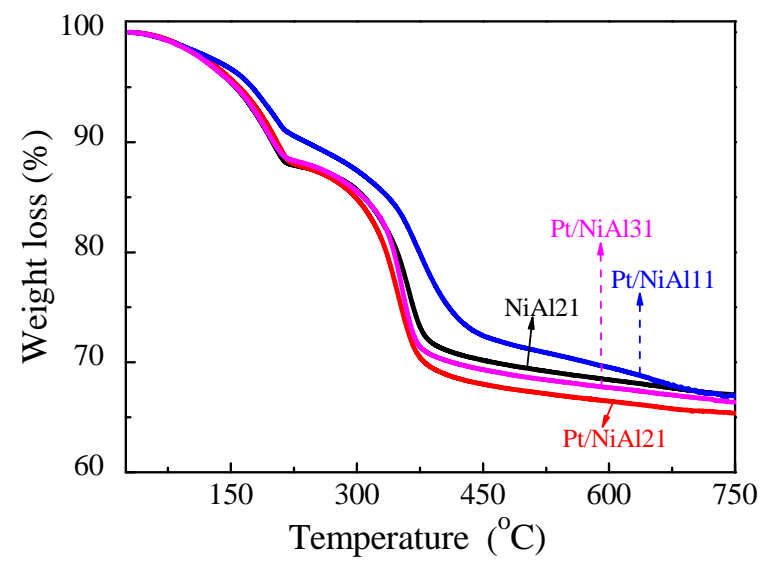

Fig. 6. TG curves of NiAl21, Pt/NiAl11, Pt/NiAl21 and Pt/NiAl31. 

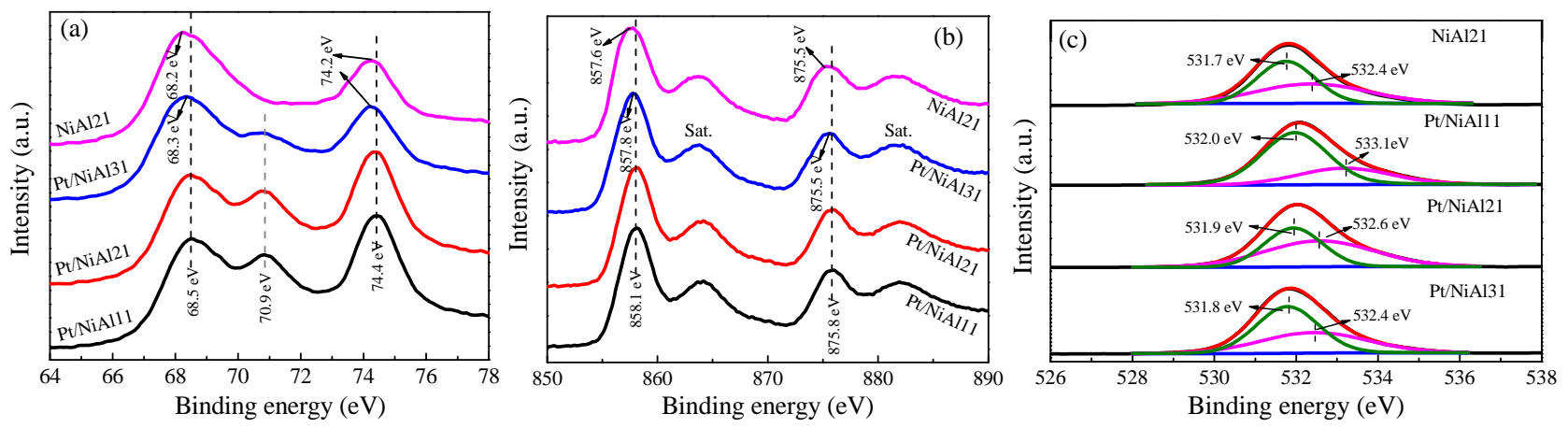

Fig. 7. XPS analysis of NiA21, Pt/NiAl11, Pt/NiA21 and Pt/NiAl31 catalysts. (a) Al 2p and Pt 4f; (b) Ni 2p; (c) 0 1s.

Fig. 7(c) shows the 01 s spectra of NiA21, Pt/NiAl11, $\mathrm{Pt} / \mathrm{NiA} 21$ and Pt/NiAl31 catalysts. The deconvoluted peaks with binding energies at 531.7-532.0 and 532.4-533.1 eV are assigned to lattice oxygen $\left(\mathrm{O}_{\mathrm{L}}\right)$ and surface hydroxyl $(\mathrm{OH}) /$ surface adsorbed oxygen $\left(\mathrm{O}_{\text {ads }}\right)$ like $\mathrm{H}_{2} \mathrm{O}$ and active oxygen species, respectively. The ratios of the surface hydroxyl $(\mathrm{OH})$ /surface adsorbed oxygen $\left(\mathrm{O}_{\text {ads }}\right)$ to lattice oxygen $\left(\mathrm{O}_{\mathrm{L}}\right)$ based on XPS analysis are listed in Table 1 . It can be observed that with increasing the ratio of $\mathrm{Ni} / \mathrm{Al}$, the $\left(\mathrm{O}_{\mathrm{ads}}+\mathrm{OH}\right) / \mathrm{O}_{\mathrm{L}}$ increased and then declined. Pt/NiAl21 showed the highest proportions of $\mathrm{O}_{\text {ads }}$ and $\mathrm{OH}$, which will favor the catalytic oxidation of $\mathrm{HCHO}$ at room temperature. Furthermore, in comparison to NiAl21, Pt/NiAl21 exhibited a higher proportion of $\mathrm{O}_{\text {ads }}$ and $\mathrm{OH}$. This result further indicates that the Pt deposition promoted the formation of active $\mathrm{OH} / \mathrm{O}_{\mathrm{ads}}$, which will involve in $\mathrm{HCHO}$ catalytic oxidation reaction. Moreover, it also indicates a strong interaction between Pt nanoparticles and the support [23], consistent with the XPS analysis of Ni $2 p$.

The reducibility of NiAl21, Pt/NiAl11, Pt/NiA21 and $\mathrm{Pt} / \mathrm{NiAl31}$ samples was investigated by $\mathrm{H}_{2}$-TPR and compared in Fig. 8. A strong peak centered at $381{ }^{\circ} \mathrm{C}$ for Pt/NiAl11, at 365 ${ }^{\circ} \mathrm{C}$ for Pt/NiA21 and at $369{ }^{\circ} \mathrm{C}$ for Pt/NiAl31 can be attributed to the reduction of adsorbed oxygen species on the surface of the catalysts and/or the reduction of $\mathrm{Ni}^{2+}$ interacting with $\mathrm{Pt}$. Two broad bands centered at 535 and $677^{\circ} \mathrm{C}$ for Pt/NiAl11 are

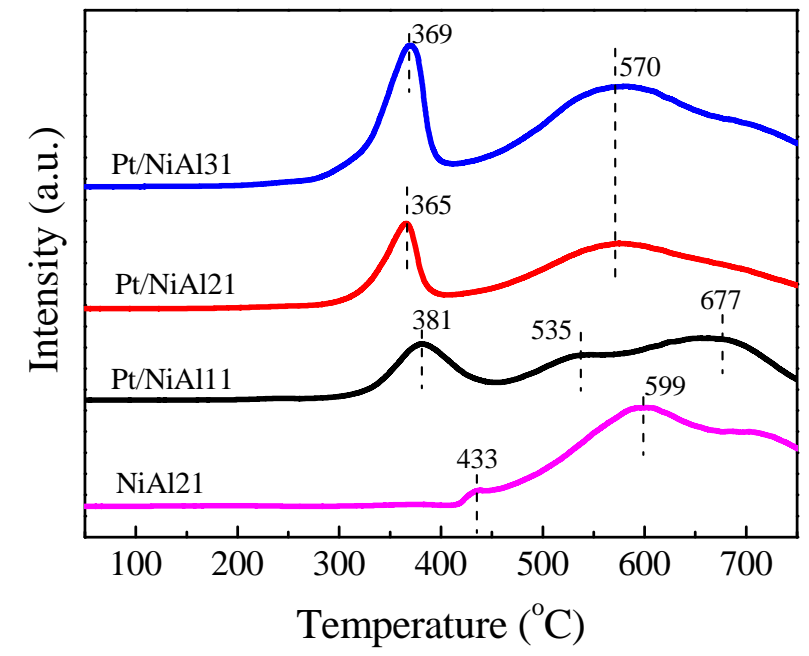

Fig. 8. $\mathrm{H}_{2}$-TPR profiles of NiA21, Pt/NiAl11, Pt/NiA21 and Pt/NiAl31 samples. due to the reduction of $\mathrm{Ni}^{2+}$ weakly interacting with $\mathrm{Al}(\mathrm{OH})_{3}$ and in the form of bulk NiAl-LDHs, respectively; while a broad band centered at $570{ }^{\circ} \mathrm{C}$ for $\mathrm{Pt} / \mathrm{NiA} 21$ and $\mathrm{Pt} / \mathrm{NiAl} 31$ is due to the reduction of $\mathrm{Ni}^{2+}$ in bulk NiAl-LDHs. Compared with Pt/NiAl11, Pt/NiA21 and Pt/NiAl31 showed a lower temperature associated with the reduction of adsorbed oxygen species. This indicates more reactivity of the adsorbed oxygen species on the surfaces of Pt/NiAl21 and Pt/NiAl31 catalysts. In addition, a broad band centered at $599{ }^{\circ} \mathrm{C}$ accompanied with a shoulder at a lower temperature of ca. $433{ }^{\circ} \mathrm{C}$ is observed for NiAl21, which is related to the reduction of bulk $\mathrm{Ni}^{2+}$ and surface oxygen species in NiAl-LDHs, respectively. In comparison with that of NiAl21, Pt/NiA21 exhibited stronger reduction peak of adsorbed surface oxygen species together with a much lower temperature. This implies that Pt addition facilitates the formation of adsorbed surface oxygen species with better reactivity. These adsorbed surface oxygen species will play an important role in HCHO oxidation.

\subsection{Catalytic HCHO oxidation performance}

The catalytic performances of Pt/NiAl11, Pt/NiAl21 and $\mathrm{Pt} / \mathrm{NiAl} 31$ for HCHO oxidation at room temperature are compared in Fig. 9. The HCHO concentration over the three catalysts decreased (Fig. 9(a)), and accordingly the $\mathrm{CO}_{2}$ concentration increased (Fig. 9(b)), illustrating the complete decomposition of $\mathrm{HCHO}$ into $\mathrm{CO}_{2}$ and water over these catalysts at room temperature. The ratio of $\mathrm{Ni} / \mathrm{Al}$ has an obvious effect on the catalytic performance of the catalysts. With increasing the ratio of $\mathrm{Ni} / \mathrm{Al}$, the activity of the obtained samples increased and then decreased, and ranked as follows: Pt/NiAl21 > Pt/NiAl31 $>\mathrm{Pt} / \mathrm{NiAl} 1$. For example, after an hour the HCHO concentration decreased from 223.8 to $16.9 \mathrm{ppm}$ for Pt/NiAl21; 223.4 to 69.1 ppm for Pt/NiAl1, and 227.2 to $32.7 \mathrm{ppm}$ for Pt/NiAl31. Accordingly, the $\Delta \mathrm{CO}_{2}$ increased to 293, 238 and $285 \mathrm{ppm}$ for Pt/NiAl21, Pt/NiAl1 and Pt/NiAl31, respectively. Moreover, in the first $20 \mathrm{~min}$ of the reaction time, Pt/NiAl21 displayed a much faster rate in the decrease of HCHO concentration than $\mathrm{Pt} / \mathrm{NiAl} 31$ and Pt/NiAl1. This suggests that Pt/NiAl21 had a fast kinetics of HCHO oxidation. The superior activity of Pt/NiAl21 can be attributed to the more amount of surface oxygen species, the stronger interaction between $\mathrm{Pt}$ and $\mathrm{Ni}$, and largest specific surface area. Interestingly, Pt/NiAl21-c showed 

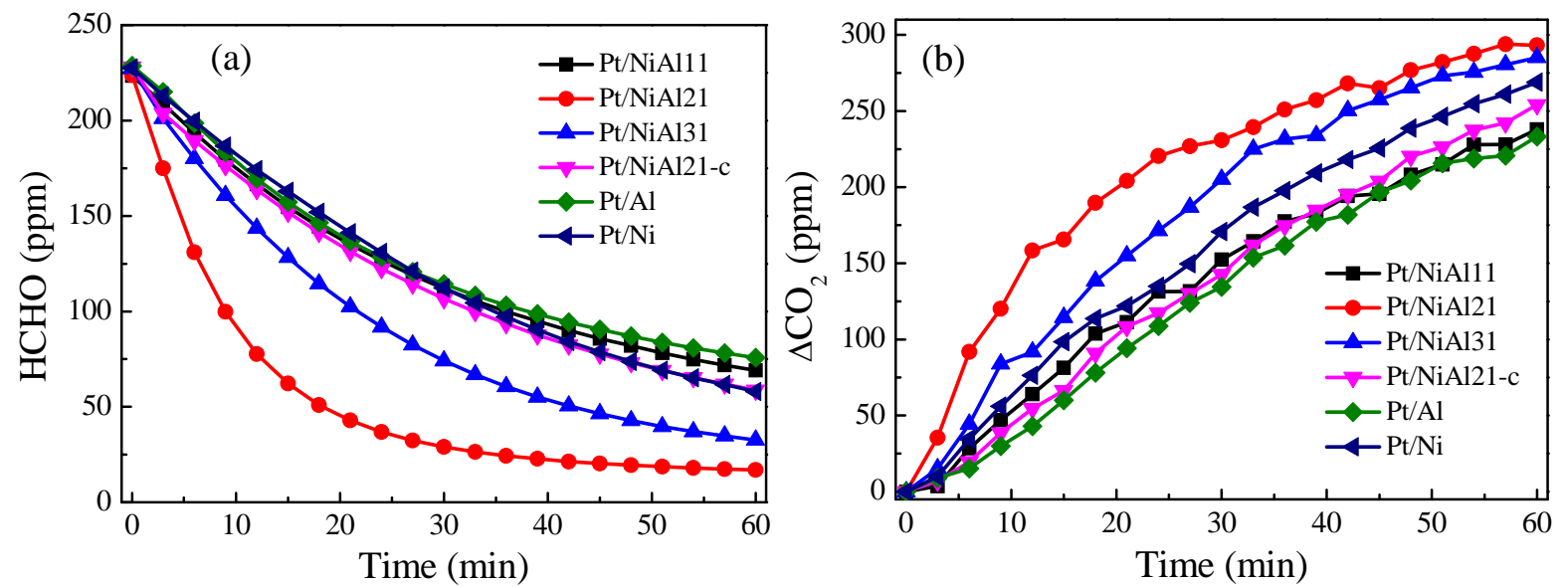

Fig. 9. Dependence of $\mathrm{HCHO}$ concentration decrease (a) and $\mathrm{CO}_{2}$ concentration increase (b) on reaction time over Pt/NiAl11, $\mathrm{Pt} / \mathrm{NiAl} 21, \mathrm{Pt} / \mathrm{NiAl} 31$, $\mathrm{Pt} / \mathrm{NiAl21-c,} \mathrm{Pt} / \mathrm{Al}$ and $\mathrm{Pt} / \mathrm{Ni}$.

a much lower HCHO decrease compared to that of Pt/NiAl21. It is easy to understand that the loss of surface oxygen species after long time heat-treatment. This further confirms the importance of surface oxygen species in oxidation of HCHO. Furthermore, Pt/NiAl21 also possessed a good stability for HCHO oxidation (Fig. 10), with no significant decline in HCHO removal efficiency in the following repeated recycles as compared to that in the first run. It implies that the Pt/NiAl21 catalyst can be a promising alternative for $\mathrm{HCHO}$ decomposition at room temperature. It has to be noted that the NiAl21, NiAl31 and NiAl11 supports had negligible adsorption or catalytic oxidation performances for gaseous HCHO (not shown). So, the catalytic activity of the three catalysts resulted from the Pt deposition. However, the different supports actually influenced the catalytic performance of the catalysts due to the difference in the composition, surface hydroxyls and interaction between Pt and supports.

\subsection{In situ DRIFTS study of HCHO oxidation}

In situ DRIFTS analysis is used to investigate the possible reaction mechanism of $\mathrm{HCHO}$ oxidation over the samples. The in situ DRIFTS of HCHO oxidation over NiAl21 and Pt/NiAl21

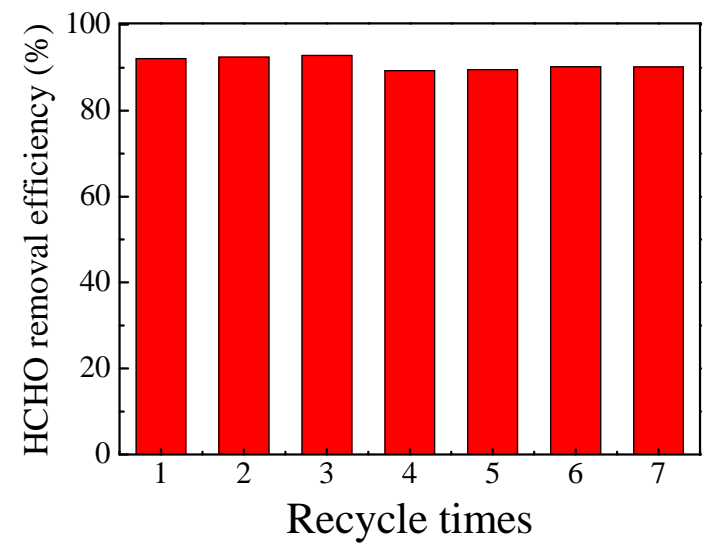

Fig. 10. HCHO removal efficiency after $1 \mathrm{~h}$ of reaction time over the $\mathrm{Pt} / \mathrm{NiAl} 21$ catalyst in seven repeated tests. were compared in Fig. 11. As shown in Fig. 11(a) and (b), the negative peak at ca. $3691-3698 \mathrm{~cm}^{-1}$ due to the vibration of $\mathrm{OH}$ suggested the consumption of active surface hydroxyls. The peaks at ca. 2893-2898, 2802-2810, 1585-1590, 1362-1368, 1270-1291 and 1082-1092 $\mathrm{cm}^{-1}$ increased with reaction time and remained stable after $40 \mathrm{~min}$. The two small bands at 2893-2898 and 2802-2810 $\mathrm{cm}^{-1}$ are attributed to $v(\mathrm{C}-\mathrm{H})$ stretch of formate; the bands at 1585-1590 and 1362-1368 $\mathrm{cm}^{-1}$ are assigned to $v_{\mathrm{as}}(\mathrm{OCO})$ and $\mathrm{v}_{\mathrm{s}}(\mathrm{OCO})$ adsorbed on the surfaces of the samples [43,44], and those at 1270-1291 and $1082-1092 \mathrm{~cm}^{-1}$ are ascribed to $\tau\left(\mathrm{CH}_{2}\right)$ and $v(\mathrm{CO})$ in DOM [45], respectively. In addition, a peak at ca. $1120 \mathrm{~cm}^{-1}$ for NiAl21 is attributed to $\rho\left(\mathrm{CH}_{2}\right)$ in DOM [45]. The above results illustrate HCHO molecules are partially oxidized into formate/DOM species over NiAl21. However, the decrease concentration of HCHO was ignorable for pure NiAl-LDHs in the performance tests. This is caused by a high concentration of tested HCHO, few of which chemically adsorbed on NiAl-LDHs and subsequently deactivated NiAl-LDHs due to incomplete oxidation. Closer observation is found that a broad band at 3020-3600 $\mathrm{cm}^{-1}$ attributed to the adsorbed water appeared for Pt/NiAl21, implying the formation of $\mathrm{H}_{2} \mathrm{O}$ during $\mathrm{HCHO}$ oxidation. Together with the result of $\mathrm{HCHO}$ removal tests, it indicates the complete mineralization of $\mathrm{HCHO}$ into $\mathrm{CO}_{2}$ and $\mathrm{H}_{2} \mathrm{O}$ over Pt/NiAl21 at room temperature.

Here, a possible reaction mechanism for $\mathrm{HCHO}$ oxidation on $\mathrm{Pt} / \mathrm{NiAl} 21$ catalyst was proposed. First, $\mathrm{HCHO}$ and $\mathrm{O}_{2}$ molecules diffused on the suface of the hierarchical structures Pt/NiAl21, $\mathrm{O}_{2}$ molecules on the suface of metallic Pt NPs are dissociated to active $\mathrm{O}$ atoms. The adsorbed $\mathrm{HCHO}\left([\mathrm{HCHO}]_{s}\right)$ was oxidized to formate species $\left([\mathrm{HCOO}]_{s}\right.$ ) by the surface oxygen species (e.g. $[\mathrm{OH}]_{s}$ ) of the catalyst. Then the formate species are further oxidized into $\mathrm{CO}_{2}$ and $\mathrm{H}_{2} \mathrm{O}$ by the surface hydroxyl groups of the catalyst, as indicated by Eqs. (1)-(5). Because of the active 0 atoms interacting with the water on the surface of the catalyst, hydroxyl groups $\left([\mathrm{OH}]_{s}\right)$ can be replenished in the HCHO oxidation process over the Pt/NiAl21 catalyst, therefore, Pt/NiAl21 catalyst presents excellent catalytic properties for HCHO decomposition. 

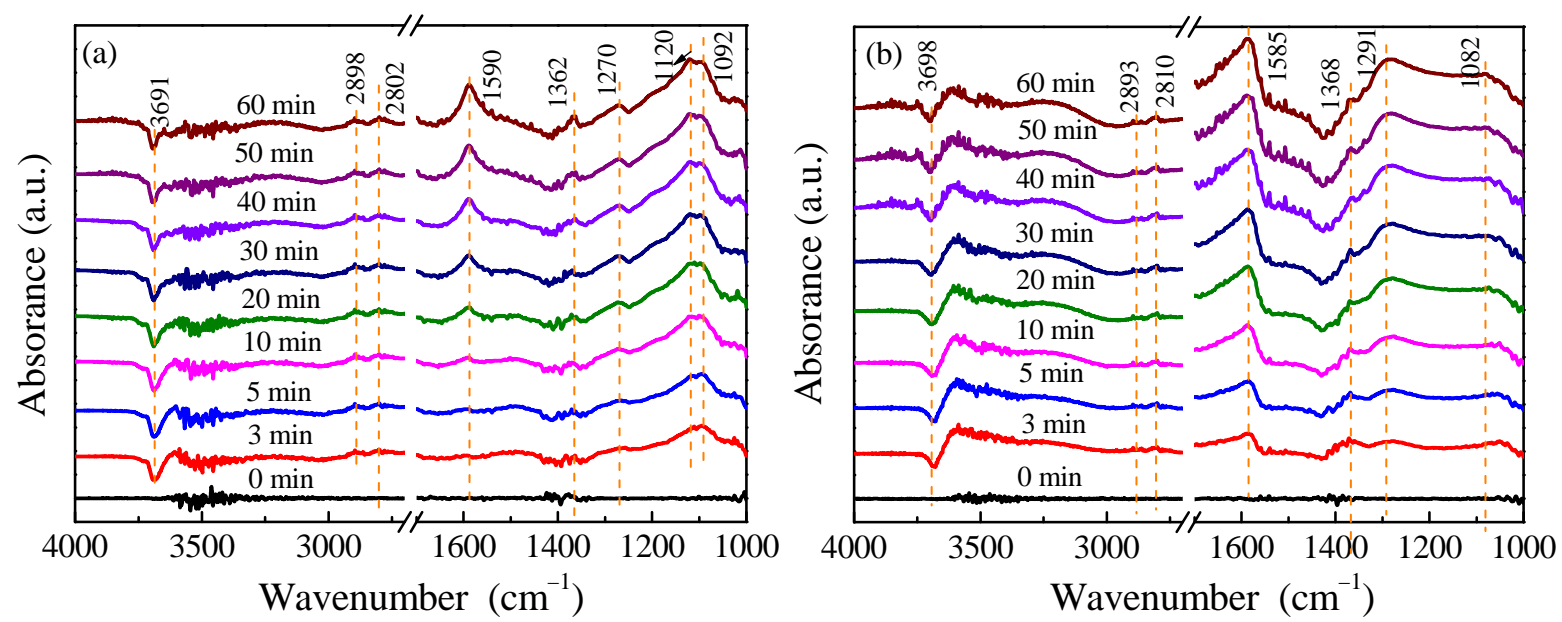

Fig. 11. Dynamic changes of in situ DRIFT spectra of NiAl21 (a) and Pt/NiAl21 (b) as a function of time in a flow of $\mathrm{HCHO}+\mathrm{O}_{2}$ at room temperature.

$$
\begin{gathered}
{[\mathrm{HCHO}]+\mathrm{M} \rightarrow[\mathrm{HCHO}]_{s}+\mathrm{M}(\mathrm{M}=\mathrm{Pt} / \mathrm{NiAl} 21)} \\
\mathrm{O}_{2}+\mathrm{Pt} \rightarrow 2[\mathrm{O}]_{s}+\mathrm{Pt} \\
{[\mathrm{O}]_{s}+\left[\mathrm{H}_{2} \mathrm{O}\right]_{s} \rightarrow 2[\mathrm{OH}]_{s}} \\
{[\mathrm{HCHO}]_{s}+[\mathrm{OH}]_{s} \rightarrow[\mathrm{HCOO}]_{s}+2[\mathrm{H}]_{s}} \\
{[\mathrm{HCOO}]_{s}+[\mathrm{OH}]_{s} \rightarrow \mathrm{CO}_{2}(\mathrm{~g})+\mathrm{H}_{2} \mathrm{O}(\mathrm{g})}
\end{gathered}
$$

\section{Conclusions}

The catalyst (Pt/NiAl21) prepared via hydrothermal method followed by $\mathrm{NaBH}_{4}$ reduction exhibited relatively excellent catalytic activity toward $\mathrm{HCHO}$ oxidation, and $\mathrm{HCHO}$ can be completely oxidized into $\mathrm{CO}_{2}$ at room temperature. The enhanced catalytic performance of Pt/NiAl21 is attributed to its large amount of reactive surface oxygen species, unique flower-like structure and high specific surface area. XRD pattern and HRTEM image reveal that Pt is in a very high dispersion degree on NiAl21. In stiu DRIFTS results suggest that formate species is the main reaction intermediates. We propose that the surface hydrorxyl groups play a key role for HCHO oxidation. The study demonstrates that Pt/NiAl21 can act as efficient catalyst to be widely applied in indoor HCHO removal.

\section{References}

[1] C. Zhang, H. He, Catal. Today, 2007, 126, 345-350.

[2] Q. Xu, W. Lei, X. Li, X. Qi, J. Yu, G. Liu, J. Wang, P. Zhang, Environ. Sci. Technol., 2014, 48, 9702-9708.

[3] Z. H. Xu, J. G. Yu, G. Liu, B. Cheng, P. Zhou, X. Y. Li, Dalton Trans., 2013, 42, 10190-10197.

[4] D. Sun, Y. Le, C. Jiang, B. Cheng, Appl. Surf. Sci., 2018, 441, 429-437.

[5] Z. H. Xu, J. G. Yu, J. X. Low, M. Jaroniec, ACS Appl. Mater. Interfaces, 2014, 6, 2111-2117.

[6] Z. Xu, J. Yu, W. Xiao, Chem. Eur. J., 2013, 19, 9592-9598.

[7] J. G. Yu, X. Y. Li, Z. H. Xu, W. Xiao, Environ. Sci. Technol., 2013, 47, 9928-9933.

[8] J. Ye, X. Zhu, B. Cheng, J. Yu, C. Jiang, Environ. Sci. Technol. Lett., 2017, 4, 20-25.

[9] Z. Zhu, R. J. Wu, J. Taiwan Inst. Chem. Eng., 2015, 50, 276-281.

[10] J. Wang, R. Yunus, J. Li, P. Li, P. Zhang, J. Kim, Appl. Surf. Sci., 2015, 357, 787-794.

[11] S. Huang, X. Zhu, B. Cheng, J. Yu, C. Jiang, Environ. Sci. Nano, 2017,
4, 2215-2224.

[12] J. Zhang, Y. Li, L. Wang, C. Zhang, H. He, Catal. Sci. Technol., 2015, 5, 2305-2313.

[13] Y. Duan, S. Song, B. Cheng, J. Yu, C. Jiang, Chin. J. Catal., 2017, 38, 199-206.

[14] X. Zhu, B. Cheng, J. Yu, W. Ho, Appl. Surf. Sci., 2016, 364, 808-814.

[15] H. Huang, X. Ye, H. Huang, L. Zhang, D. Y. C. Leung, Chem. Eng. J., 2013, 230, 73-79.

[16] F. Xu, Y. Le, B. Cheng, C. Jiang, Appl. Surf. Sci., 2017, 426, 333-341.

[17] B. Bai, J. Li, J. Hao, Appl. Catal. B, 2015, 164, 241-250.

[18] J. Zhou, L. Qin, W. Xiao, C. Zeng, N. Li, T. Lv, H. Zhu, Appl. Catal. B, 2017, 207, 233-243.

[19] M. Jia, H. Bai, Zhaorigetu, Y. Shen, Y. Li, J. Rare Earths, 2008, 26, 528-531.

[20] Z. Yan, S. Gong, L. An, L. Yue, Z. Xu, React. Kinet. Mech. Catal., 2018, 124, 293-304.

[21] N. An, P. Wu, S. Li, M. Jia, W. Zhang, Appl. Surf. Sci., 2013, 285, 805-809.

[22] B. B. Chen, X. B. Zhu, M. Crocker, Y. Wang, C. Shi, Appl. Catal. B, 2014, 154-155, 73-81.

[23] Z. Yan, Z. Xu, J. Yu, M. Jaroniec, Environ. Sci. Technol., 2015, 49, 6637-6644.

[24] B. Liu, Y. Liu, C. Li, W. Hu, P. Jing, Q. Wang, J. Zhang, Appl. Catal. B, 2012, 127, 47-58.

[25] Z. Yan, Z. Xu, B. Cheng, C. Jiang, Appl. Surf. Sci., 2017, 404, 426-434.

[26] B. B. Chen, X. B. Zhu, M. Crocker, Y. Wang, C. Shi, Catal. Commun., 2013, 42, 93-97.

[27] Z. Xu, J. Yu, M. Jaroniec, Appl. Catal. B, 2015, 163, 306-312.

[28] Z. Yan, Z. Xu, J. Yu, M. Jaroniec, Appl. Catal. B, 2016, 199, 458-465.

[29] Z. Yan, B. Zhu, J. Yu, Z. Xu, RSC Adv., 2016, 6, 50128-50137.

[30] B. Wang, G. R. Williams, Z. Chang, M. H. Jiang, J. F. Liu, X. D. Lei, X. M. Sun, ACS Appl. Mater. Interfaces, 2014, 6, 16304-16311.

[31] Y. Y. Du, Q. Jin, J. T. Feng, N. Zhang, Y. F. He, D. Q. Li, Catal. Sci. Technol., 2015, 5, 3216-3225.

[32] Z. Yan, Z. Yang, Z. Xu, L. An, F. Xie, J. Liu, J. Colloid Interface Sci., 2018, 524, 306-312.

[33] Z. Gao, J. Wang, Z. Li, W. Yang, B. Wang, M. Hou, Y. He, Q. Liu, T. Mann, P. Yang, M. Zhang, L. Liu, Chem. Mater., 2011, 23, 3509-3516.

[34] Y. Zou, X. Wang, Y. Ai, Y. Liu, J. Li, Y. Ji, X. Wang, Environ. Sci. Technol., 2016, 50, 3658-3667.

[35] H. Lu, Q. Li, H. Xiao, R. Wang, D. Xie, Am. J. Anal. Chem., 2014, 5, 547-558. 


\section{Graphical Abstract}

Chin. J. Catal., 2018, 39: 1919-1928 doi: 10.1016/S1872-2067(18)63143-2

Hierarchical Ni-Al hydrotalcite supported Pt catalyst for efficient catalytic oxidation of formaldehyde at room temperature

Zhaoxiong Yan, Zhihua Xu *, Lin Yue, Ling Shi, Lingyong Huang *

Jianghan University; Huanggang Normal University

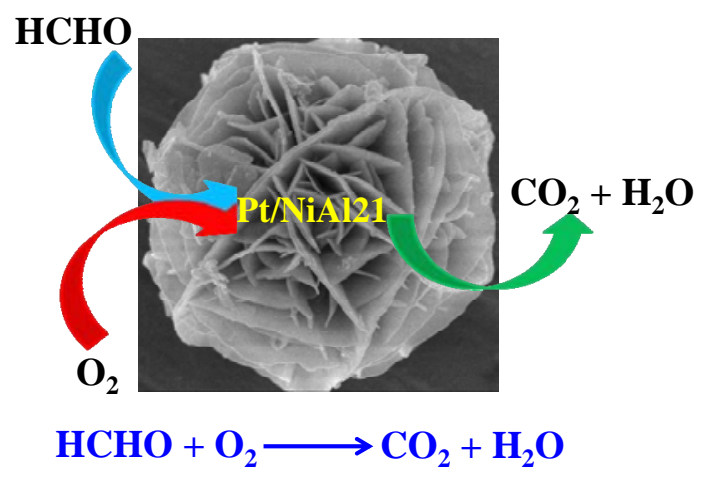

(Room temperature)

$\mathrm{Ni}-\mathrm{Al}$ hydrotalcite supported $\mathrm{Pt}$ catalyst (Pt/NiAl21) showed an excellent activity toward room-temperature decomposition of HCHO into $\mathrm{CO}_{2}$ and $\mathrm{H}_{2} \mathrm{O}$ due to its plenty of reactive surface oxygen species and unique flower-like structure.

[36] A. Antonakos, E. Liarokapis, T. Leventouri, Biomaterials, 2007, 28, 3043-3054.

[37] K. S. W. Sing, D. H. Everett, R. A. W. Haul, L. Moscou, R. A. Pierotti, J. Rouquerol, T. Siemieniewska, Pure Appl. Chem., 1985, 57, 603-619.

[38] J. S. Valente, J. Prince, A. M. Maubert, L. Lartundo-Rojas, P. del Angel, G. Ferrat, J. G. Hernandez, E. Lopez-Salinas, J. Phys. Chem. C, 2009, 113, 5547-5555.

[39] Q. Liu, G. Fan, S. Zhang, Y. Liu, F. Li, Mater. Lett., 2012, 82, 4-6.

[40] N. Ohtsu, M. Oku, T. Shishido, K. Wagatsuma, Appl. Surf. Sci., 2007,
253, 8713-8717.

[41] X. H. Huang, G. H. Li, B. Q. Cao, M. Wang, C. Y. Hao, J. Phys. Chem. C, 2009, 113, 4381-4385.

[42] M. Wei, X. Xu, X. Wang, F. Li, H. Zhang, Y. Lu, M. Pu, D. G. Evans, X. Duan, Eur. J. Inorg. Chem., 2006, 2831-2838.

[43] G. Busca, J. Lamotte, J. C. Lavalley, V. Lorenzelli, J. Am. Chem. Soc., 1987, 109, 5197-5202.

[44] S. J. Park, I. Bae, I. S. Nam, B. K. Cho, S. M. Jung, J. H. Lee, Chem. Eng. J., 2012, 195-196, 392-402.

[45] T. Kecskés, J. Raskó, J. Kiss, Appl. Catal. A, 2004, 273, 55-62.

\section{分等级结构的镍铝水滑石负载Pt催化剂高效室温催化氧化甲醛

\author{
a 江汉大学光电化学材料与器件教育部重点实验室及工业烟尘污染控制 \\ 湖北省重点实验室, 湖北武汉430056 \\ b黄冈师范学院催化材料制备及应用湖北省重点实验室, 湖北黄冈438000
} \\ 严朝雄 ${ }^{\mathrm{a}}$, 徐志花 ${ }^{\mathrm{a}}{ }^{*}$, 岳 琳 ${ }^{\mathrm{a}}$, 石 零 ${ }^{\mathrm{a}}$, 黄林勇 ${ }^{\mathrm{b}, \#}$}

摘要: 甲醛是室内空气中常见的一种挥发性有机物, 严重危害人体健康. 去除室内空气中甲醛污染物对保障人体健康具有 重要意义. 在众多的去除甲醛方法中, 室温催化氧化法能在室温条件下将甲醛彻底氧化成无毒的 $\mathrm{CO}_{2}$ 和 $\mathrm{H}_{2} \mathrm{O}$, 具有催化剂能 重复使用、不会导致二次污染、无需额外能量输入和特殊装置等优点, 因而广受关注. 在该方法中, 效率高和稳定性好的 催化剂设计和制备是关键. 目前有效的室温去除甲醛催化剂一般是负载贵金属型催化剂. 据报道, 载体(例如载体成分、微 结构及表面羟基等)在很大程度上影响负载贵金属型催化剂的活性. 我们结合镍铝水滑石含有丰富的表面羟基有利于甲醛 气体的吸附和花球状多孔结构有利于反应/生成物的传输, 以及 $\mathrm{Ni}$ 具有可变化学价态能与贵金属形成强烈的相互作用等优 势, 制备了分等级结构的镍铝水滑石(NiAl-LDHs)负载Pt复合催化剂(Pt/NiAl-LDHs), 并探讨了其在室温条件下催化分解甲 醛的活性.

以 $\mathrm{Ni}\left(\mathrm{NO}_{3}\right)_{2} 、 \mathrm{Al}\left(\mathrm{NO}_{3}\right)_{3}$ 、尿素和 $\mathrm{NH}_{4} \mathrm{~F}$ 为原料, 采用水热法制备了分等级结构花球状的 $\mathrm{NiAl}-\mathrm{LDHs}$, 然后采用浸渍- $\mathrm{NaBH}$ 估 
还原法在其表面负载Pt纳米颗粒, 从而制备了Pt/NiAl-LDHs复合催化剂; 研究了 Ni/Al摩尔比对Pt/NiAl-LDHs催化剂室温催 化分解甲醛性能的影响. 采用XRD、FTIR、TG、SEM、TEM、EDS、XPS和 $\mathrm{H}_{2}$-TPR等对所制样品进行表征和分析, 结果 表明, 花球状结构的Pt/NiAl-LDHs催化剂是由交错连接的纳米片组成, 沉积的Pt纳米颗粒约3-4 nm. 当 Ni/Al比为2:1时催化 剂(Pt/NiAl21)显示出最好的室温催化氧化甲醛性能. 经过7次循环使用后, Pt/NiAl21催化剂仍然保持很高的甲醛去除效率, 表明其具有良好的稳定性. 这主要与其独特的花球状多孔结构、丰富的表面活性氧物种及较大的比表面积等有关. 根据性 能测试结果及原位红外光谱分析, 我们认为在室温条件下, Pt/NiAl21催化剂先将甲醛氧化成甲酸盐和二氧亚甲基(DOM)中 间体, 然后再进一步将其氧化成 $\mathrm{CO}_{2}$ 和 $\mathrm{H}_{2} \mathrm{O}$. 甲酸盐和 $\mathrm{DOM}$ 中间体的氧化是甲醛催化氧化过程中的控制步骤. 本文可为高 效室温催化氧化甲醛复合催化剂的设计和制备提供思路.

关键词: 水滑石; 镍铝水滑石; 分等级结构; 催化氧化; 甲醛去除

收稿日期: 2018-05-25. 接受日期: 2018-07-20. 出版日期: 2018-12-05.

*通讯联系人. 电话: 13409925284; 传真: (027)84225198; 电子信箱: xuzhihua78@sina.com

\#通讯联系人. 电话: 18871361314; 传真: (027)84225198; 电子信箱: Ly_huang2003@163.com

基金来源：国家自然科学基金(21577046, 21307038); 武汉市青年科技晨光计划(2017050304010327); 江汉大学光电化学材料与 器件教育部重点实验室开放基金(JDGD-201813).

本文的电子版全文由Elsevier出版社在ScienceDirect上出版(http://www.sciencedirect.com/science/journal/18722067). 